\title{
PROJEKT BASE EROSION AND PROFIT SHIFTING
}

\author{
PETR NOVOTNÝ
}

\begin{abstract}
Project Base Erosion and Profit Shifting
The text deals with the issue of the base erosion and profit shifting as an instrument tackling tax avoidance schemes. This paper points out the particular questions arising from the regulation and stresses the impacts on the tax payers and investors. Finally, the author evaluated the Czech approach to the base erosion and profit shifting.
\end{abstract}

Keywords: base erosion; profit shifting

Klíčová slova: base erosion; profit shifting

DOI: $10.14712 / 23366478.2017 .39$

Projektu Base Erosion and Profit Shifting, tedy narušování daňových základů a přesouvání zisků do jiných zemí (dále jen „BEPS“) věnuje odborná veřejnost pozornost již několik let. Politickým důvodem vzniku tohoto projektu byly úniky informací o vyhýbání se zdanění, pro které se vžila novinářská označení jako Luxembourg Leaks nebo Panama Papers a jeho cílem je zamezit tzv. agresivnímu daňovému plánování. ${ }^{1}$

Projekt byl zahájen v roce 2013 zprávou OECD, nazvanou Řešení problému narušování daňových základů a přesouvání zisků do jiných zemí. Vedoucí projektu, Raffaele Russo, při vzniku projektu konstatoval, že „Projekt BEPS vznikl z uvědoměni si skutečnosti, že daňové struktury (vytvořené nadnárodními společnostmi za účelem snižení jejich daňových odvodů) jsou ve většině připadů zcela legální, takže problém tkví nikoli $v$ těchto strukturách, ale v daňových pravidlech jako takových. My se nyní pouśtíme do změny těchto pravidel, aby tyto postupy již legální nebyly." OECD vymezilo tyto základní cíle BEPS: (i) zastavit ztrátu daní z prŕíjmů právnických osob pro státní rozpočty, (ii) zajistit, aby př́ijmy byly zdaňovány tam, kde byla vytvořena ekonomická hodnota a (iii) přestavět daňové systémy, aby byly spravedlivé a pro poplatníky důvěryhodné.

V rámci projektu BEPS byla 24. listopadu 2016 vydána tzv. Multilaterální konvence $^{2}$, dále jen „MLI“, která byla označena jako krok „,k nejvýznamnějšímu prepsá-

1 Tento text byl zpracován v rámci programu „PROGRES Q02 - Publicizace práva v evropském a mezinárodním srovnání" realizovaného v roce 2018 na Právnické fakultě Univerzity Karlovy.

2 Multilateral Convention to Implement Tax Treaty Related Measures to Prevent Base Erosion and Profit Shifting. 
ní mezinárodnich daňových pravidel za posledních sto let" ${ }^{3}$ MLI by měl být mnohostrannou úmluvou, která by byla základem pro simultánní vyjednání změn ve více než 3000 stávajících dvoustranných smluv o zamezení dvojího zdanění. MLI se zaměřuje na implementaci poznatků získaných v rámci BEPS tím, že navrhuje změnu těch ustanovení smluv o zamezení dvojího zdanění, která dle názoru jeho autorů umožňují, např. proto, že nejsou dostatečně sladěná s vnitrostátní legislativou, aby se korporace vyhnuly zdanění. Důležité je uvědomit si, že BEPS a v jeho rámci ani MLI, neslouží k potírání daňových úniků, ale k odstranění dosud zcela legální možnosti mezinárodního daňového plánování, které je nyní označováno jako agresivní daňové plánování a které, alespoň dle autorů projektu BEPS, je nutné odstranit.

$\mathrm{V}$ praxi by měl být postup takový, že nejprve státy podepíší a ratifikují MLI - přičemž předpokladem úplného zavedení je i to, že si státy (některé z nich) nevyhradí žádná práva na neuplatňování některých ustanovení MLI a následně budou smlouvy o zamezení dvojího zdanění, uzavřené smluvními stranami MLI modifikovány tak, aby s ním byly v souladu. Do projektu MLI jsou zařazeny jurisdikce, které projekt podepsaly - Česká republika tak učinila 7. 6. 2017 a které do projektu přihlásily smlouvy o zamezení dvojího zdanění, které by měly být upraveny ve smyslu MLI (Česká republika přihlásila všech 87 smluv o zamezení dvojího zdanění). Současně je však zapotřebí podotknout, že dle usnesení vlády ze dne 15. 5. 2017 Česká republika přijme jen tzv. minimální standardy. Finální seznam výhrad a oznámení ČR bude předložen do konce roku 2017.

Ustanovení MLI je rozděleno do třech kategorií - první skupinu tvoří tzv. minimální standardy, tedy minimální úrovně harmonizace smluv o zamezení dvojího zdanění, druhou skupinu tvoří ustanovení, která budou implementována do smluv o zamezení dvojího zdanění, pokud si strany nevyhradí opak a třetí skupina bude zahrnuta do smluv o zamezení dvojího zdanění jen za podmínky, že si tato ustanovení strany výslovně zvolí.

V rámci tzv. minimálního standardu musí smlouvy o zamezení dvojího zdanění obsahovat (i) preambuli jasně deklarující, že účelem smlouvy je zamezit př́ležitostem vyhýbání se zdanění, (ii) test hlavního účelu transakce (principal purpose test - PPT) jde o úpravu, podle které bude zakázáno, aby korporace využila výhodu plynoucí ze smlouvy o zamezení dvojího zdanění, pokud je zřejmé, že jedním z hlavních důvodů uskutečnění konkrétní obchodní transakce nebo nastavení konkrétní korporátní struktury je získání této daňové výhody a (iii) závazek smluvních stran řešit spory plynoucí ze smlouvy o zamezení dvojího zdanění postupem pro dosažení vzájemné dohody (mutual agreement procedure-MAP).

Druhá kategorie ustanovení MLI upravuje (i) pravidla pro zdanění příjmů transparentních entit, (ii) zdanění osob majících dvojí daňové rezidenství, (iii) zdanění dividend, (iv) zdanění stálé provozovny (se zaměřením na provozovny ve třetích zemích) a (v) pravidla proti vzniku stálé provozovny. Do třetí kategorie se řadí (i) alternativy pro správnou aplikaci metod zamezení dvojího zdanění, (ii) alternativy boje proti zneuŽívání výjimek pro vznik stálé provozovny, (iii) zjednodušená aplikace omezení výhod

3 OECD/G20, Base Erosion and Profit Shifting Project, Information Brief, 2015. 
plynoucích ze smlouvy o zamezení dvojího zdanění na tzv. kvalifikované subjekty, tedy subjekty, které splňují stanovené podmínky (Limitation of Benefits), (iv) rozhodčí doložka pro řešení sporů, které se nepodaří vyřešit vzájemnou dohodou apod.

Ustanovení MLI mají být do smluv o zamezení dvojího zdanění implementována tak, že doplní stávající text smlouvy v případě, že daná úprava ve smlouvě není vůbec obsažena nebo nahradí stávající text tam, kde je smlouva s MLI v rozporu. Ustanovení spadající do tzv. třetí kategorie mohou být do smlouvy o zamezení dvojího zdanění implementována jen na základě výslovné volby obou smluvních stran.

Pokud jednotlivá ustanovení MLI bliže vysvětlíme, je zřejmé, že již tzv. minimální standard zcela obrací původní smysl smluv o zamezení dvojího zdanění. Obecně deklarovaným a přijímaným účelem smluv o zamezení dvojího zdanění totiž byla snaha státu zamezit dvojímu zdanění, tedy zamezit tomu, aby zahraniční př́ijem rezidenta jednoho státu dosažený ze zdrojů na území druhého smluvního státu podléhal zdanění v obou těchto státech. Vyplývalo to z logiky, že nadměrné zdanění by demotivovalo daňové subjekty, pokud jde o podnikání v zahraničí, což by bylo v rozporu s ekonomickými zájmy státu - ten se naopak snažil, aby jeho rezidenti dosahovali př́ijem i v zahraničí, a naopak zahraniční investoři umistovali své investice do daného státu a dosahovali zde své př́ijmy. Preambule smluv o zamezení dvojího zdanění ve smyslu MLI jde proti tomuto dosavadnímu účelu a deklaruje naopak, že účelem smlouvy o zamezení dvojího zdanění je zamezit tzv. dvojímu nezdanění, tedy případu, kdy by daný příjem nebyl zdaněn $\mathrm{v}$ žádném smluvním státu. MLI vychází z toho, že stávající preambule smluv o zamezení dvojího zdanění obsahují účel plynoucí z jejich označení - tedy zabránit dvojímu zdanění, a doplňuje jej slovy ,aniž by tím byly vytvořeny př́ležitosti k nezdanění nebo sniženému zdanění prostřednictvím zkrácení daně nebo vyhýbání se zdaněni".

Skutečnost, že je za daňový únik považována transakce, která nemá jiný účel, než využít daňového zvýhodnění, je judikována již opakovaně Soudním dvorem EU i Nejvyšším správním soudem. Za zneužití práva v oblasti daňové je považováno ziskání výhody ze stanovených pravidel umělým vytvořením podmínek pro její získání. ${ }^{4} \mathrm{Jinými}$ slovy, za zakázané jednání se považuje takové jednání, které nemá zcela jasný (jiný než daňový) ekonomický racionálně odůvodněný smysl. Institut zneužití práva se v rámci MLI dále rozšiřuje tím, že za něj považuje i takové jednání, pokud jedním z hlavních (tedy nikoli jediným) důvodů takového jednání bude získání daňové výhody. Je zcela zřejmé, že takovéto pojetí vytvoří celou řadu interpretačních problémů. Otázka míry zdanění je zcela logickou a legitimní úvahou při každé podnikatelské transakci. MLI tímto širokým pojetím PPT dává prostor pro to, aby každá transakce, která svému subjektu - díky formě nebo místě realizace - umožní nulové nebo nižší zdanění, byla automaticky považována za nelegální, protože jedním z jejích (hlavních) důvodů bylo nižší zdanění. Vůbec mi není jasné, jak budou daňové subjekty v takových př́ípadech prokazovat, že daňová optimalizace jejich podnikatelský záměr vůbec neovlivnila.

Pokud jde i transparentní entity, tedy subjekty, jejichž zisk je zcela nebo zčásti zdaňován na úrovni jejich společníků (beneficientů, zpravidla fyzických osob - např. ve-

4 Rozsudek Nejvyššího správního soud ČR ze dne 15. 10. 2015 sp. zn. 9 Afs 57/2015. 
řejné obchodní společnosti, komanditní společnosti, trusty apod.), zakotvuje MLI pravidlo, podle něhož musí být odmítnuta výhoda zakotvená smlouvou o zamezení dvojího zdanění ve vztahu k takovému př́ijmu, který by pak - podle vnitrostátních předpisů - nepodléhal zdanění v žádném smluvním státu. Smlouva o zamezení dvojího zdanění bude moci být aplikována jen na ty př́ijmy rezidenta smluvního státu, které budou podléhat zdanění alespoň $v$ jednom smluvním státě. $K$ neoprávněné výhodě by mohlo dojít $v$ př́ípadě, kdy stát zdroje považuje př́ijemce - rezidenta druhého státu za netransparentní entitu, smlouva upravuje zdanění ve státě rezidenta, nicméně druhý stát považuje příjemce za transparentní entitu a proto jí náležející př́ijem nedaní.

Právnické osoby, které by byly daňovými rezidenty ve dvou státech, nebudou moci využít výhodu plynoucí ze smlouvy o zamezení dvojího zdanění, dokud se strany nedohodnou bud' na jediné rezidenci pro účely smlouvy, nebo na konkrétních výhodách, které se daňovému subjektu poskytnou bez ohledu na jeho rezidenství.

Situaci, kdy by konkrétní př́ijem nebyl zdaněn ani ve státě zdroje, ani ve státě, jehož je prríjemce daňovým rezidentem, řeší MLI tak, že si smluvní státy budou moci vybrat ze tří variant (přičemž je jim zachováno i právo nevybrat si žádnou z alternativ). První alternativou je, že nezdanění v jurisdikci, jejímž je poplatník rezidentem, je podmíněno zdaněním ve státě zdroje daného př́ijmu. Druhá varianta se týká dividend a zakazuje, aby dividenda, která nepodléhá zdanění ve státě rezidenta, byla současně považována za daňově uznatelný náklad ve státě zdroje. Třetí alternativa vychází z toho, že zamezení dvojího zdanění by nebylo realizováno metodou vynětí, ale toliko započtením daně zaplacené ve státě zdroje.

MLI reaguje i na problém označovaný jako treaty shopping, kterým se rozumí stěhování sídla společnosti do států s příznivějším daňovým režimem, někdy označované jako spekulativní výběr daňové jurisdikce. Opatření MLI je zamířené proti subjektům využívajícím takové společenskoprávní uspořádání, jehož cílem je získání výhod plynoucích ze smlouvy o zamezení dvojího zdanění rezidentem nesmluvního státu tím, že ve smluvním státu založí společnost, která nemá žádnou podstatu (společnost typu letterbox - poštovní schránka). Na tyto subjekty by měla být vždy uplatněna zásada PPT - principal purpose test (test hlavního účelu transakce) i zásada LOB - Limitation of Benefits, omezující výhody plynoucí ze smlouvy o zamezení dvojího zdanění na kvalifikované subjekty, tedy takové poplatníky, kteří splňují předem stanovené podmínky pro přiznání výhody.

Daňové zvýhodnění pro dividendy vyplácené společností mající sídlo v jednom smluvním státě, jejichž př́ijemcem je rezident druhého smluvního státu, by mělo být podle MLI přiznáno jen na základě splnění předem stanovených kritérií ovládání společnosti prŕíjemcem dividendy. Tato kritéria navíc budou muset zůstat splněná po dobu 365 dní včetně dne výplaty dividendy.

V některých smlouvách o zamezení dvojího zdanění je specificky upraveno zdanění zisku z prodeje akcií nebo podílů tzv. nemovitostních společností tak, že tyto kapitálové výnosy jsou daněny ve smluvním státě, ve kterém se nacházejí nemovitosti (za situace, kdy převážná část hodnoty zcizovaných akcií/podílů pramení právě z nemovitostí). MLI doplňuje, že toto místo zdanění zůstává zachováno i v př́ípadě, že uvedená podmínka byla splněna kdykoli v průběhu 365 dnů před zcizením akcií. 
MLI se věnuje i př́ípadům, kdy je př́ijem korporace - rezidenta smluvního státu považován její domovskou jurisdikcí za prŕjem přičítaný stálé provozovně ve druhém smluvním státě a z tohoto důvodu není ve státě rezidenta zdaňován. MLI požaduje, aby v př́ípadě, že tento prŕjem nesouvisí s aktivní podnikatelskou činností provozovanou stálou provozovnou a je ve druhém státě zdaňován velmi nízkou daňovou sazbou, byla výhoda smlouvy o zamezení dvojího zdanění odňata a př́ijem byl zdaněn ve státě, kde je korporace rezidentem. Nutno podotknout, že odnětí výhody plynoucí ze smlouvy o zamezení dvojího zdanění může být domovským státem zrušeno na základě důvodné žádosti poplatníka.

Za zcela zásadní krok je možné považovat aktualizaci definice stálé provozovny, nikoli však v tom smyslu, že by rozetnula spor, zda tzv. službová stálá provozovna, tedy poskytování služeb po určitou dobu (při splnění časového testu) bez trvalého zařízení k podnikání, jak některé smlouvy o zamezení dvojího zdanění vyžadují, je či není stálou provozovnou. MLI se soustřed’uje na to, jak zabránit zneužívání negativní definice stálé provozovny (tedy př́ípadů podnikatelské činnosti, které se, ač by byly vykonávány v trvalém zařízení pro podnikání, za stálou provozovnu nepovažují. Podle MLI se definice stálé provozovny rozšiří na situace, kdy (i) osoba jedná za společnost, (ii) nečiní tak v rámci své obvyklé podnikatelské činnosti nezávislého zástupce, (iii) zpravidla, tedy opakovaně, uzavírá smlouvy nebo podniká kroky směřující k jejich uzavření, (iv) smlouvy takto uzavřené jsou standardními smlouvami, které nevyžadují zásadní vyjednávání ze strany společnosti a současně (iv) tyto smlouvy společnost zavazují v tom smyslu, že znějí na jméno společnosti nebo se v nich jedná o služby nebo průmyslová práva společnosti. K tomu MLI upřesňuje, že na osobu, která jedná výhradně jako zástupce jedné nebo více propojených společností, nemůže být pohlíženo jako na nezávislého zástupce.

Tzv. reprezentace, které nebyly považovány za stálou provozovnu, budou mít zachován tento zvýhodněný režim výhradně pro př́ípady vykonávání činností „podpưrného nebo prípravného charakteru“. K tomu uvádí komentář OECD, že činnost je činností přípravného charakteru, pokud ,je vykonávána v rámci uvažování o (se zřetelem) $k$ výkonu činnosti, která predstavuje nepostradatelnou a podstatnou část podniku jako celku“ a činností podpůrného charakteru je činnost, která ,je vykonávána za účelem podpořeni nepostradatelné a podstatné části činnosti podniku jako celku, aniž by tvorila její součást“. Zmírňující alternativa umožňuje zachovat výjimku pro vznik stálé provozovny pro konkrétní stanovené činnosti, aniž by bylo současně vyžadováno, aby byla splněna podmínka činnosti př́pravného nebo podpůrného charakteru.

MLI se zabývá i otázkou zneužívání časového testu pro vznik stálé provozovny, typicky stavební nebo montážní projekty. Zde je v praxi jedna smlouva často rozdělena na více dílčích kontraktů, které samy o sobě časový test nesplňují, aby bylo zabráněno vzniku stálé provozovny. MLI pro účely vzniku stálé provozovny zakotvuje pravidlo, že časové období pro staveniště nebo konkrétní projekt bude vypočteno jako součet činností provedených předmětným podnikem nebo koncernem na takovém staveništi/ projektu, kde každá z těchto činností trvala déle než 30 dní.

Základní výhodu MLI spatřuje např. Piergiorgio Velente v tom, že „umožňnje jurisdikcím prokázat, po ratifikaci, svoji vůli upravit své smlouvy o zamezení dvojího zdanění 
tak, aby byly v souladu s MLI. Po ratifikaci všemi stranami dané dohody je predmètná smlouva o zamezení dvojího zdanění v souladu s MLI a v souladu se v̌̌emi ostatními smlouvami o zamezení dvojího zdanění, které byly upraveny v souladu s MLI. Tímto dojde $k$ úspoře obrovských nákladů, které by jinak musely být vynaloženy na opětovné vyjednáváni tisícu jednotlivých smluv o zamezení dvojího zdanění, a zároveň to pomũže vyhnout se riziku vzniku odlišných podmínek v rưzných smlouvách o zamezení dvojího zdanění, pokud by takové dohody musely být znovu vyjednávány jednotlivě." 5

Je zcela zřejmé, že pokud se podaří završit projekt MLI do konce a jednotlivé státy, které se k projektu dosud přihlásily, skutečně dohodu uzavřou a ratifikují, čeká nás opravdová revoluce v mezinárodním zdanění a sjednocení těch ustanovení smluv o zamezení dvojího zdanění, která dosud byla nebo mohla být využita pro tzv. agresivní daňové plánování, tedy plánování podnikatelského záměru motivovaného snížením míry zdanění. Je však otázkou, zda mají opatření proti „,agresivnímu“ daňovému plánování, tedy legální daňové optimalizaci, ekonomický smysl pro ekonomiky typu České republiky, která až dosud motivovala zahraniční investory k umístění investic právě výhodným korporátním zdaněním. V okamžiku, kdy bude každá zahraniční investice podrobena PPT, tedy testu hlavního účelu transakce, je samožrejmě zcela reální riziko, že o tuto svou „konkurenční výhodu“ země typu České republiky přijdou a investor raději nebude rozšiřovat svou podnikatelskou činnost mimo jurisdikci svého domovského státu. V této souvislost proto považuji za správný krok, že se Česká republika přihlásila toliko k minimálním standardům a věŕm, že vyhrazené avízované výjimky, které má ČR předložit do konce roku, budou natolik zásadní, že se negativním dopadům MLI vyhneme.

JUDr. Petr Novotný, Ph.D.

Univerzita Karlova, Právnická fakulta

novotnyp@prf.cuni.cz

ORCID: 0000-0002-0630-1977

5 VELENTE, Piergiorgio: BEPS Action 15: Release of Multilateral Instrument, Intertax, Kluwer Law Online, 2017 